\title{
Encouraging science outreach
}

\author{
President Obama recently called for more scientist involvement in education. Science outreach programs are very \\ welcome, but to be effective, they must include incentives for teachers and better training for scientist volunteers.
}

T his April, in a speech to the National Academy of Sciences, President Obama announced new initiatives for science research and education and challenged scientists to use their knowledge to think about creative ways to engage young people in science and engineering and to improve student achievement in math and science. Although scientists should heed this call to action and do their best to engage young students and educators, true change will require both better incentives for teachers to buy into these reform efforts and more systematic training and incentives for scientists to participate in educational outreach.

Several reports indicate that US primary education in mathematics and science needs a boost. According to statistics released by the US Department of Education at the end of 2008, neither US fourth or eighth graders showed any detectable change in science achievement in 2007 compared to 1995 (http://nces.ed.gov/timss/results07_science95.asp). Only 28\% of US high school students are well prepared for college-level biology (http://www.act.org/news/data/08/data.html). The state of science and math education has increasingly attracted the attention of not only policymakers and educators but also scientists and engineers. As a result, there have been several initiatives aimed at taking professional scientists into the classroom, with the assumption that this involvement will improve public science education, both by providing better science content and, more critically, by allowing students to imbibe an inquirybased learning process from those working at the bench.

Such outreach programs would also seem to benefit scientists. Many scientists have been dismayed by policy decisions that are not based on good scientific evidence and have despaired at science taking a back seat in the public discourse of issues that affect them-be it animal rights activism, stem cell research or the teaching of intelligent design in schools. Aiding educators in teaching good science and instilling in children an interest in and understanding of how science works would help create a future taxpayer base that has a positive impression of publicly funded research. Critically, by helping bring inquiry-based teaching methods into schools, scientists would presumably be able to foster critical thinking in the next generation.

Recently, many more scientists have become involved in attempts to improve public science education. Programs designed either to provide basic science content and creative science teaching tools to teachers or to encourage scientists to form partnerships with their local schools have mushroomed across the country. Nick Spitzer, the head of the Society for Neuroscience Public Education and Communication Committee, says that that there has been an increase in the number of members involved in science education outreach efforts as evidenced by participation levels in SfN's public education programs. A $2007 \mathrm{SfN}$ survey found that 50\% of the members surveyed indicated that they would be interested in participating in educational outreach. SfN has launched the NERVE virtual encycloportal and recently announced a Wiki initiative aimed at making basic neuroscience information more accessible to educators and pupils. Several universities run outreach programs with their local schools-volunteering scientific expertise at science fairs, running teacher training programs or arranging for scientists to visit classrooms. SfN also maintains a list of members who are interested in forming scientist-teacher partnerships with local schools.

Undoubtedly, these content-delivery tools could aid dedicated teachers who have the enthusiasm, drive and resources to access and take advantage of creative ways to introduce science in their classrooms. Many teachers, however, simply do not have the resources to reform their science curricula, and probably only a small percentage take advantage of these online resources or of the many scientists who sign up to partner with teachers. Sending in scientists to educate these teachers' classes is unlikely to be the solution-scientists, no matter how enthusiastic, just cannot be good replacements for trained teachers in the classroom. Many have little idea of what goes on in an average science class or how the curricula are regulated, and they do not have the skills to effectively educate $\mathrm{K}-12$ students, especially those who are struggling with basic reading and writing skills or with social issues outside the classroom.

Reforming how science is taught in schools, and the amount of it that is taught, will ultimately depend heavily on how many teachers think that scientists can contribute something to the primary and secondary education process and who thus incorporate those contributions into their lessons. Given the current burdens on educators, teachers need to be better rewarded for efforts to implement a more inquiry-based culture in their classrooms. For the most part, such changes will have to come from within the education system.

That does not mean that scientists cannot help. A recent report by the Organisation for Economic Co-operation and Development on science education (http://www.oecd.org/dataoecd/44/17/42645389.pdf) reports that top performing students in science get involved in science-related activities outside school, and although they report feeling well prepared for science-related careers, only around half say they are well informed about such careers. Scientists are well placed to help in both these areas. However, to be truly successful at engaging children, scientists must be better trained to teach and communicate with the public. They also should be rewarded for participating in these efforts; one option would be to give young scientists teaching credits for participating in these outreach efforts. Designing training programs that would help young scientists acquire these skills and rewarding young scientists for sacrificing part of their time at the bench to participate in educational outreach would go a long way toward building effective teacher-scientist partnerships. Science outreach ought to be encouraged and fostered, not least because the scientific enterprise ultimately depends on good science being taught in the classroom. 